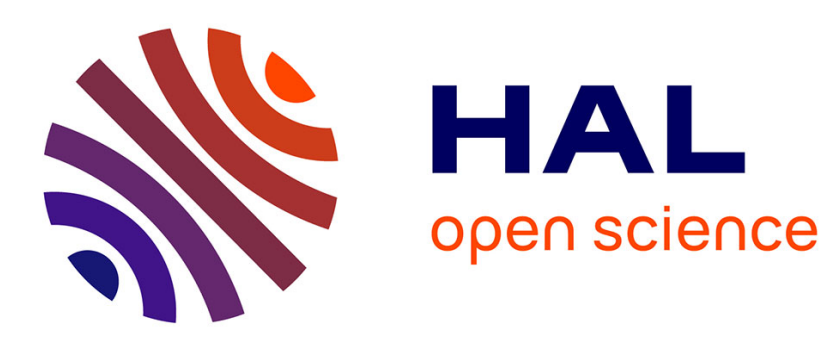

\title{
How ecological indicators construction reveals social changes. The case of lakes and rivers in France
}

\author{
Gabrielle Bouleau, C. Argillier, Y. Souchon, C. Barthélémy, M. Babut
}

\section{To cite this version:}

Gabrielle Bouleau, C. Argillier, Y. Souchon, C. Barthélémy, M. Babut. How ecological indicators construction reveals social changes. The case of lakes and rivers in France. Ecological Indicators, 2009, 9, p. 1198 - p. 1205. 10.1016/j.ecolind.2009.03.010 . hal-00455355

\section{HAL Id: hal-00455355 https://hal.science/hal-00455355}

Submitted on 10 Feb 2010

HAL is a multi-disciplinary open access archive for the deposit and dissemination of scientific research documents, whether they are published or not. The documents may come from teaching and research institutions in France or abroad, or from public or private research centers.
L'archive ouverte pluridisciplinaire $\mathbf{H A L}$, est destinée au dépôt et à la diffusion de documents scientifiques de niveau recherche, publiés ou non, émanant des établissements d'enseignement et de recherche français ou étrangers, des laboratoires publics ou privés. 


\title{
How ecological indicators construction reveals social changes - the case of lakes and rivers in France

\author{
Gabrielle Bouleau $^{\mathrm{a}, \mathrm{b}}$, Christine Argillier $^{\mathrm{c}}$, Yves Souchon ${ }^{\mathrm{d}}$, Carole Barthélémy $^{\mathrm{e}}$, Marc Babut ${ }^{\mathrm{d}}$ \\ ${ }^{a}$ Cemagref, UMR G-EAU, 361 rue Jean-François Breton, F-34196 Montpellier, France \\ ${ }^{\mathrm{b}}$ LAEP, University of California, Berkeley, USA \\ ${ }^{\mathrm{c}}$ Cemagref, UR HYAX, F-13182 Aix en Provence, France \\ ${ }^{\mathrm{d}}$ Cemagref, UR BELY, F-69336 Lyon, France \\ ${ }^{\mathrm{e}}$ Université de Provence Aix-Marseille 1, LPED, UMR IRD 151 France
}

\begin{abstract}
Social and scientific factors are deeply enmeshed in each other within the development and the use of ecological indicators (EI). Yet low research has assessed which factors contribute to selecting ecological indicators on the long-term. This article proposes to study the historical construction of EI by examining ecological, political, and social background of specific places where EI were developed, in France on lakes and rivers. Our major findings in France were that ecological indicators were never optimised for the present market or political arena. Instead EI development was typically recycling previous tools that were elaborated for other purposes by environmentally committed outsiders, without regular funding. We found that regular funding for monitoring an EI was only provided when it matched an institution's goal. Beyond the geographically limited relevance of the case studies, these results therefore improve the theoretical framework we deploy when constructing or relying on indicators.
\end{abstract}

\section{Key words}

Science and Technology Studies, History, Social Studies, Ecological Indicator, Freshwater, France.

\section{Introduction}

For forty years, ecological concerns have spread beyond scientific spheres. Public interest and investment for ecosystems have been growing, notably for wetlands, rivers, and lakes. As a consequence, many agencies are developing so-called 'ecological restoration' projects the efficacy of which is not always obvious (Kondolf, Anderson et al. 2007). Ecological indicators (EI) are meant to support decisions in order to set restoration priorities and/or to assess whether the proposed management will improve ecological conditions or not, or to appraise completed projects. Despite increasing developments in the field of EIs during the last thirty years (Barbour, Swietlik et al. 2000; Kallis and Nijkamp 2000; Moog and Chovanec 2000; Wasson, Chandesris et al. 2003), many scientists complain that such indicators are hardly used to support decisions, management plans, and programs evaluations ((Dale and Beyeler 2001; Lenz and Peters 2006). They usually attribute the gap separating the creation and the use of EI to social factors (Turnhout, Hisschemöller et al. 2006). Therefore, research addressing the social perspective of EI has been developed recently. Yet such work focuses on short-term analyses. It has mainly addressed what social drivers are responsible for using or not using EI, once EI have been designed by scientists.

The recent literature on this topic falls in two categories: the market or the political arena as driving forces. In the first category, a market is presumed to exist for EI in which environmental scientists, the providers, must fulfil the expectations of decision makers, the buyers. In this perspective, authors recommend that EI be reliable, cheap, easy to use (Cairns and Pratt 1993; Lenat and Barbour 1994). They should provide users with the information they need in a form they can understand (Shields, Solar et al. 2002; McNie 2007) according to their tasks, responsibilities, and values. Different problems in which scientists, politicians, and experts have different roles, may therefore require different indicators (Turnhout, Hisschemöller et al. 2006). Even so, Ribaudo et al. (2001) noticed there is a need for generalised indicators which meet multiple objectives. In this market-like perspective, social demands challenge EI that were designed under purely scientific considerations. These authors suggest that 
To be cited as : Bouleau, G., C. Argillier, Y. Souchon, C. Barthélémy and M. Babut (2009). "How ecological indicators construction reveals social changes - the case of lakes and rivers in France." Ecological Indicators 9 (6): 1198-1205.

defining indicators with stakeholders' participation improves their chance of success. In the second category, EI are not presumed to compete in a market but rather in a political arena. Each indicator is believed to promote a particular political point of view. Indeed, the ecological status of an ecosystem depends on the boundaries chosen for the system and on the characteristics chosen to be restored. Scholars adopting this perspective insist on the plurality of ecological objectives (Higgs 1994; Jackson, Lopoukhine et al. 1995) and consider that defining restoration goals and objectives is a value-based activity (Lackey 2001). In this second perspective, economical and technical characteristics of indicators are hardly addressed. Emphasis is put on the expression of choices made within any indicator. Both categories may overlap since the frontier between science, market and policy is a fuzzy area (Davis and Slobodkin 2004; Hobbs 2004; Turnhout, Hisschemöller et al. 2006). In both perspectives, authors have addressed a small feedback loop between science and policy in which social factors act as selection forces for useful or compelling EI, which in turn are meant to supply data for adaptive management and policy changes if required (Fig. i).

To date, very little attention has been paid to the manner values or expectations of stakeholders influence the development of EI prior to selection. Determining the role the social context plays in EI development requires a historical perspective to study a larger feedback loop (Fig. ii). This paper develops a method to study long-term interactions between EI development and social factors. Social factors are understood here to designate all dynamics within human society including structural constraints and human agency. We elaborate an analytical framework to account for these interactions. Then we apply this approach to five case studies in France on lakes and rivers (saprobic index, test on minnows, biotic index, fish index and rapid diagnosis). Last we conclude on the interest of this new approach which provides new elements for explaining the gap between production and use of EI.

\section{An analytical framework to study the long-term co-evolution of EI and society}

Managing the environment and the human population is a recent concern of states. Foucault argues that western governments and scientists became interested in indicators only in the last 150 years, as governmental legitimacy shifted from expansionism to optimizing the well-being of domestic population. As political definitions of well-being evolved, they reshaped the scientific agenda (Foucault 1978-79). Scientific facts are not simply given, but selected by actors to make sense at one point (Fleck 1979; Latour 1987). Access to nature influences data collecting (Forsyth 2003). Power structures influence the way experts define crises (Trottier 2008). In turn, experts' discourses spur new social demand. This longterm dynamic changes relationships between technology and society (Callon 1986; Latour 1987; Star and Griesemer 1989; Sabatier and Jenkins-Smith 1993). This applies for EI as well. Exploring their history sheds light on the manner EI evolve, are selected and kept and how in turn, they influence knowledge and social representations (Fig. ii). This research identifies such long-term influences. For this purpose, we propose an analytical framework to sketch a new approach for social studies of EI, which is (1) interdisciplinary, (2) inductive, and (3) historical.

(1) A social study of EI requires a multidisciplinary dialogue between social and natural sciences. Social representations of nature are simultaneously influenced by the scientific state of the art, with which biologists are more familiar, and by the cultural and political context of the period, which social scientists know better. Both competencies are needed. They should not be separate; they should provide different assumptions for the same research questions. Once this is achieved this multidisciplinary approach has yielded an interdisciplinary framework (Trottier and Slack 2004).

(2) An inductive and qualitative approach allows emerging concepts to be incorporated during the research (Bryman and Burgess 1994; Altheide 1996). In doing so, we identify causal relationships that may be significant even though not being always necessary nor sufficient. We advocate focusing on a small set of largely used indicators rather than studying many different ones. We look for factors that were significant at least in one case study. 
To be cited as : Bouleau, G., C. Argillier, Y. Souchon, C. Barthélémy and M. Babut (2009). "How ecological indicators construction reveals social changes - the case of lakes and rivers in France." Ecological Indicators 9 (6): 1198-1205.

(3) Without questioning the validity of scientific methods used, we explain how social factors historically influenced the choice of species and the finality of research. For this purpose, we define constitutive elements of the historical trajectory of an EI: the historical background of places where it was developed, the way data were collected and treated, what ecological knowledge was available, what belief concerning nature and society was spread, and what were the ecological management goals. We elaborate on the variation-selection-retention model of socio-environmental co-evolution developed by Kallis (2007): why different social groups promoted different representations of nature (variation), how a mainstream representation emerged (selection) and how it was maintained despite possible criticisms (retention). The variation step received very little attention in previous academic work. A second layer of evolution was also missing in previous short-term analyses. Scholars often considered society as a homogeneous entity one could represent in one box (Fig. i and ii). To account for the social evolution, we propose to split the social component into two elements (Fig. iii), one representing what is established (institutions, law) and one representing more evolving social features (coalitions, representations).

This analytic framework enables to address cumulative effects, historical opportunities, technological gridlocks and path-dependence of EI that are otherwise ignored.

\section{Case study background and method}

The recent evolution of freshwater quality and its relationship with EI development are well documented. Experts generally agree that in western countries, during the 1960s, increasingly visible environmental catastrophes spurred public support for environmental legislation. This resulted in pieces of law as the Clean Water Act in the USA (Barbour, Swietlik et al. 2000) and the first Council Directives in the European Community addressing water quality (Aubin and Varone 2002). The adopted legislation has proven to be generally efficient in addressing point-source chemical pollution but is too narrowly focused to deal with habitat degradation that became more obvious once industrial and urban discharges into streams were reduced (Karr 1993). EI development appeared as a secondary social response to this initial improvement in chemical quality of freshwater. Yet the knowledge and the data used to design EI were developed much sooner in the last century. Therefore a study stretching back to the late nineteenth century was necessary to understand what data was available and what social representations framed (or were framed by) the emergence of EI in France.

Identifying consistent periods during which water management was uniform is difficult. Transitions emerge slowly from several, sometimes conflicting, influences. Yet, several-decade phases offer convenient time intervals to identify social changes affecting water management. Three main periods are presented within the scope of our study. In the first phase (1900-1959), the quality of surface water became a national issue for fishermen and hygienists as they developed specific sectors for drinking water and fishing. In the second phase (1960-1980) economists and urban planners began to worry about the availability of water resources and they developed a sector to treat pollution. In the third phase (since 1980) a social demand for ecosystems management grew at the European level and promoted water body restoration.

Our research project was undertaken by two sociologists and three freshwater biologists. Sociologists undertook in depth interviews with actors having played different roles in different places (managers, scientists, activists, policy makers ...). They conducted thirty-two 2-3 hour semi-structured interviews with people involved in the design or the use of five indicators in France - i.e. saprobic index (Kolkwitz and Marsson 1908), test on minnows (Phoxinus phoxinus, L.1758), biotic index (Woodiwiss 1964; Tufféry and Verneaux 1967), fish index (Oberdorff, Pont et al. 2002; Pont, Hugueny et al. 2006), and rapid diagnosis for lake (Barbe, Lavergne et al. 1990). These indicators are the most currently used by water agencies and wildlife services. Sociologists attend some field work to get familiar with methods. Freshwater biologists compiled bibliographic and ethnographic work on published and non-published ecological research. Together we analysed the evolution of available knowledge and social justifications in each document. The snowballing method was used to identify actors involved in this process. Being 
To be cited as : Bouleau, G., C. Argillier, Y. Souchon, C. Barthélémy and M. Babut (2009). "How ecological indicators construction reveals social changes - the case of lakes and rivers in France." Ecological Indicators 9 (6): 1198-1205.

affiliated to Cemagref and/or graduated from the National School of ingénieurs du GREF sometimes helped contacting officials and state engineers involved in the story. Most interviewees were contacted several times. We asked them to review their interviews and to send related personal archives. Historical studies were used for most ancient periods. We asked the actors to tell how they have been involved in the process and how they might explain choices done before they had been involved. We triangulated the results from the interviews using scientific, legal, and technical materials published at each stage to support or confront testimonies. We completed this material with bibliographical review of social works dealing with how water-related social and scientific practices and ideas have evolved during time. We compared different trajectories in order to assess whether common characteristics could be identified.

\section{Results: the development of EI in France for lakes and rivers}

In this section, we focus on three historical phases, 1900-1959, 1960-1980, and since 1980 to study five EI, namely the saprobic index, the test on minnows, the biotic index, the fish index and the rapid diagnosis for lake. All EI we studied were first set up by outsiders challenging mainstream water management. Following this phase of construction where adaptation prevailed, legal changes in law induced a shift by resting the burden of proof on other stakeholders and leading to a phase of accumulation.

\section{0-1959: Focus on fish and germs}

At the end of the $19^{\text {th }}$ Century, two social groups alerted the public to the deterioration of surface water quality in France. The first group stemmed from a handful of physicians who experienced difficulty demonstrating that water could be pathogenic. Fishing clubs made up the second group as they complained about fish depletion. Unlike epidemiologists, they did not join the hygienist movement. They advocated restocking, reducing poaching, and punishing industrial discharges. These approaches led to two different tools: the saprobic index (developed in Germany at the beginning of the $20^{\text {th }}$ century) and a poorly reliable ecotoxicological test on minnows, perfected by French legal experts at the same period. While the hygiene act of 1902 compelled to test water quality systems systematically and secured funds for nationwide surveys, French law did not acknowledge accidental pollution as a misdemeanour before 1959 and fishermen kept struggling to obtain the recognition of its impact on fish population. This difference had a major effect on the fate of the variable promoted by each group.

Sanitary actors experienced hard time in the beginning. Freshwaters were long considered very healthy in France. The miasma theory predominated, which held that odours - rather than water - were malignant. Moreover, until the mid-nineteenth century, decayed matter was considered as beneficial by most people, including a large part of physicians. Despite the initial reluctance from the medical world, some outsiders started listing organisms living in contaminated waters. They succeeded in getting other stakeholders (urban planners, engineers, politicians) interested in their hygienist ideas. These sanitary reformers made rivers suspicious as they established more relations between contaminated places and water (Goubert 1986). It took time before hygienism spread out as a political doctrine with the scientific support of German physician Robert Koch (1843 -1910) and French chemist Louis Pasteur (1822-1895) pointing out the existence of germs. The French hygiene act of 1902 resulted from this evolution and paved the way for systematic chemical and biological assessments of diversions for water supply. The first EI got stabilized in this context. German naturalists Kolkwitz and Marsson (1908) developed the "saprobic" index. It consisted of an array of organisms ranked according to their response to organic matter. Presence and abundance of saprobic organisms, those that resisted best to faecal contamination, meant risks and corresponding waters were not to be used for drinking purposes. The saprobic index became a common "passage point" (Star and Griesemer 1989) for many technologies addressing human well-being in cities. Sanitary authorities published in 1903 the first nationwide inventory of water addressing quality and updated periodically (Goubert 1986). Ironically, the sanitary perspective did not lead to any improvement of surface water quality. Since technical solutions to convey spring water or groundwater such as long aqueducts existed, urban rivers became stale. Large sewers were developed, more and more effluents 
To be cited as : Bouleau, G., C. Argillier, Y. Souchon, C. Barthélémy and M. Babut (2009). "How ecological indicators construction reveals social changes - the case of lakes and rivers in France." Ecological Indicators 9 (6): 1198-1205.

were discharged in rivers (Barles and Lestel 2007). The development of the saprobic index is a success story. Outside the mainstream medical world, a few physicians lobbied to change waste water management and ended with standardization of the EI once the law institutionalized hygienist ideas.

Fishermen were not as successful. Fishing clubs had long complained about industrial impacts. But fish depletion in freshwaters was always attributed to poaching (Barthélémy 2003) and French regulation targeted fishermen first. If ever acknowledged, pollution was considered as reversible and likely to be compensated by restocking. In case of fish mortality, claimants remained isolated outsiders. They had to provide evidence to pursue effluents dischargers. Fishing authorities would sample suspicious waters and perform tests on minnows to assess presence of toxic substances. Frequently samples were done after the toxic discharge stopped. Judges constantly considered that such cases were peculiar cases of poaching (Corbin 1995). In the late 1880s, the state promoted fishing as an accessible supply of proteins to the poor. To prevent poaching and to maintain fish populations, regardless of water quality, fishing clubs and governmental authorities agreed to raise a tax on fishermen to increase control and develop hatcheries. Since the beginning of the twentieth century, fishermen helplessly asked for a specific legislation against pollution. The ecotoxicological test on minnows failed. Its story started with isolated actors claiming for a different water management. But fishermen hardly convinced larger coalitions of actors that pollution was a problem and the law did not change. No public fund was ever secured to apply the test at large scale. Since the burden of proving pollution rested on fishing clubs, data they accumulated remained scattered, and depending on their own activism. The legal acknowledgement of any ecological dysfunction is a crucial step for EI development. It changes the need for its monitoring.

This is what happened in 1959, when pollution became punishable in France.

\section{0-1980: resource management}

Discontent fishermen suddenly found an opportunity to be listened to in 1959. As the colonial empire challenged French political influence overseas, President de Gaulle was trying to get legitimacy by paying attention to current domestic claims during emergency powers. By the edict of 1959, fishermen obtained that accidental pollution in rivers should be punished. Before the edict of 1959 , only fishermen were trying to find evidence of pollution. After this edict, polluters too suddenly became concerned. This piece of law was the impetus of a major change in the French water management, although it was not discussed by parliament and adopted during a troublesome period (Bouleau 2007). In response, industrials and municipal councils, threatened by the new edict, asked for public funds to support treatment plants. The French post-war planned administration relied on the Commissariat Général au Plan for making prospects and public policies (Colson and Cusset 2005). In this arena, many engineers were in favour of an economic and spatial approach of natural resources planning (Rabinow 1989). Influenced by Pigou's (1920) and Kneese's ideas (1962), they promoted a "polluter-pays principle" at the scale of the watershed. It was enacted by the 1964 water law which established basin agencies and basin committee (Nicolazo 1993). To apply this principle, basin committees agreed on several conventional chemical parameters in order to make pollution commensurable from upstream to downstream, in rivers and lakes: suspended matter, dissolve salts, and a combined parameter including biological and chemical oxygen demand. Basin Agencies collected levies on water users and delivered grants to fund water supply and waste water treatment facilities. Needs were huge given the post-war demographic expansion, the repatriation after the end of colonisation, and industrial development fuelled by the reconstruction economy. The focus on chemistry helped build consensus on investment priorities, but it left habitat degradation aside. The biotic index was an attempt to fill the gap on rivers. Because this story is quite recent, we were able to interview actors who promoted this new EI (Bouleau 2007).

The origin of the French biotic index dated back to the creation of a single state corps of engineers in 1965, ingénieurs du génie rural, des eaux et des forêts (IGREF), gathering "developers" of the corps of rural planners (ingénieurs du génie rural) and more "conservationist" engineers of the corps for water and forestry (Ingénieurs des eaux et des forêts). Developers promoted agricultural modernization. They 
To be cited as : Bouleau, G., C. Argillier, Y. Souchon, C. Barthélémy and M. Babut (2009). "How ecological indicators construction reveals social changes - the case of lakes and rivers in France." Ecological Indicators 9 (6): 1198-1205.

allocated state grants to farmers and rural districts in order to drain wetlands, canalize streams, raise levees against frequent floods and build dams storing winter flows for irrigation. IGREF conservationists were critical of such projects they called "anti-tank ditches", and they felt marginalized. Basin agencies did not pay attention to upstream developments, focusing on downstream urbanized and industrialized rivers, more affected by pollution. As they shared the same concern for upstream rivers, conservationists built alliances with fishing clubs, getting them organized at the State level, supporting their claims against polluting effluents and sharing material and staff. They searched an EI that would perform better than the test on minnows. As sampling was often performed after the toxic discharge had stopped, they were looking for biological sentinels proving that pollution occurred. They hired freshwater biologists "who were anglers, interested in this stuff, because this was the issue". One IGREF said to a candidate: "your one and only job is to find some stuff we could present and standardize". Tuffery and Verneaux (1967) adapted the biotic index developed by the Trent River Authority (Woodiwiss 1964) to French rivers. Verneaux (1973) identified 10 river types on the Doubs basin based on a factorial correspondence analysis of the presence or abundance of Macrobenthic Invertebrates. In the foreword of his $\mathrm{PhD}$ dissertation Verneaux recounted: "This deals with a long story which started with my father twenty-five years ago on the banks of the Doubs River and is probably going to stop in few years as the river dies". He established reference conditions correlated to a combination of abiotic variables (slope, distance to source, width, and summer temperature). Then he extended his survey and adapted the biotic index to all French rivers and got it standardized (Indice Biologique Global Normalisé, IBGN). Conservationists enlisted the biotic index in the state regular monitoring (arrêté interministériel of September 2, 1969). Following the 1976 act on nature protection, IBGN became a common tool for environmental impact assessment. Because of its initial target on accidental pollution, IBGN remained poorly relevant to point out potential disturbance of trout habitat (channel simplication, increasing temperature) by hydraulic works. IBGN had little consideration to environmental variability, which would have required much more data collecting and processing. Albeit imperfect, such an option enabled rapid development of professional training for ecological monitoring. It secured funds for monitoring activities on a regular basis, and resulted in a today-available thirty-year database.

Analysing documents concerning the biotic index, we found the same pattern of EI development as the one induced from the saprobic index case. Outsiders promoted another focus on river management, made up a new EI, enrolled allies, and obtained a legal obligation of monitoring. Our interviews revealed other aspects of the social trajectory of the biotic index. Experts focused on what they valued in personal ties and collective strategies or practices. In the case of the biotic index their preference for upstream reaches and their targeting accidental pollution were embedded in the EI they developed.

\section{0 to now: ecosystem management}

Whereas post-war industrial fast development notably improved French workers conditions, it did not thoroughly fulfil middle class expectations. Graduate employees from the baby-boom generation did not adhere completely to the stalwart praise for industrial achievements. They complained of environmental degradation. Better equipped with computers to quantitatively address ecosystem relationships, ecological scientists supported this claim (Fabiani 1985; Aspe 1995). Data collection remained the weak spot. Developers had much more data to promote their projects than ecologists had to sustain environmental preservation. The creation of the Ministry of Environment (1971) and the 1976 act requiring environmental impact assessments, were critical steps securing funding for research. But the French state would not have extended its regular monitoring without European binding legislation. It spurred the development of two other EI, the rapid diagnosis for lakes and the fish index.

Although, lake dystrophy had long been ignored by the French state, freshwater biologists of the state field station in Thonon-les-Bains initiated a local eutrophication monitoring in the sixties, after algae proliferation was observed in fishermen's gillnets in nearby Lake Geneva, the largest natural lake in France and Switzerland. They chose chlorophyll a, a chemical surrogate of the abundance of the phytoplankton to demonstrate a causal relationship between nutrients and dystrophy. Similarly Swiss 
To be cited as : Bouleau, G., C. Argillier, Y. Souchon, C. Barthélémy and M. Babut (2009). "How ecological indicators construction reveals social changes - the case of lakes and rivers in France." Ecological Indicators 9 (6): 1198-1205.

researchers started worm communities monitoring in the last 1970s (Lang 1985). This was the time when Northern American researchers supported by the "Soap and Detergent Association" published the article "We hung phosphates without a fair trial" (Legge and Dingeldein 1970 cited by Barroin 2004). Transatlantic controversies and French chemical lobbies hushed-up eutrophication alerts in France. Experts remained isolated. Managers of the Rhône Basin Agency in charge of financing restoration plans for alpine lakes finally agreed on supporting the development of a "rapid diagnosis" for lakes. Mouchel proposed to build on the trophic index developed in the United-States and Canada (Dillon and Rigler 1974; Carlson 1977; Vollenweider and Kerekes 1980; Canfield 1983). He correlated nutrient concentrations (total phosphorus, orthophosphates, total nitrogen, mineral nitrogen), transparency (Secchi depth) and chlorophyll a, and expanded results from the Alps to set up a national typology. Including then Oligochetae describing mineralization and assimilation of nutrients (Lafont 1989; Lafont, Juget et al. 1991), and a Mollusc index responding to dissolved oxygen and organic matter content within sediment (Mouthon 1993) the 'rapid diagnosis' was tested on about thirty lakes spread across different regions (Mouchel 1986; 1987; Barbe, Lavergne et al. 1990). Nevertheless this work did not lead to systematic lake monitoring in France. Resistance from lobbies defending chemical industries was strong (Barroin 2004). Political engagement for ecological preservation of lakes was low. Such EI in the making were mainly used in the Alps.

In rivers, the 1976 act on nature protection encouraged further research on impacts beyond IBGN to address morphological changes on streams. The Research Centre for Agriculture, Forestry and Rural Environment (CERAFER, which later became Cemagref) devised new methods to determine minimum instream flows downstream hydroelectric impoundments (Souchon, Valentin et al. 1998) based on American existing works (Tennant 1976; Milhous 1979; Bovee and Milhous 1982). It resulted in the adoption of the 1984 act on fishing which required minimum instream flows. Anticipating the revival of hydropower development after the oil crises, the Ministry of Environment and the National Center for Scientific Research (CNRS) decided to support environmental research on the Rhône in 1978 (PIREN Rhône). Between 1979 and 1985, scientists of the PIREN assessed the environmental impact of hydropower projects in the upper-Rhône valley. They were politically supported by ecologist activists and urban recreational users of the valley who were calling into question the power facilities. Sampling floodplain fauna and flora, they related such inventories to physical and chemical analyses. They showed evidence of seasonal longitudinal, lateral and vertical transfers between the river, the floodplain and the groundwater (Roux 1982; Castella, Richardot-Coulet et al. 1984; Amoros, Roux et al. 1987; RichardotCoulet, Castella et al. 1987). They elaborated a general deterministic understanding of the "hydrosystem" which advocated for the preservation of natural hydrological patterns in rivers. Scientific evidence and political support led to the 1992 water act. It required permits and public hearings for all developments significantly affecting water. Yet, it did not result in a national change in monitoring activities. State authorities had already much invested in collecting biochemical, IBGN and fish population data. If ecological concerns were high in the Rhône valley, they were not priorities in the rest of the country. The list of currently monitored indicators appeared to be locked-in at that level. This reduced the scope of possible data accumulation. Instead, the adaptation phase extended.

Challenged by the European on-going research and inspired by Karr's work on biological integrity (1981; 1991), French freshwater biologists developed more theoretical work. They recomputed accumulated ecological data of the Rhône to test theories of functional ecology (Statzner, Resh et al. 1994; Statzner, Resh et al. 1994; Beisel, Usseglio-Polatera et al. 1998; Usseglio Polatera, Bournaud et al. 2000). The functional approach spread out, notably at European level where it makes very different ecosystems comparable. The European political arena happens to be much more sensitive to ecologist concerns than the French one. In 2000, European Parliament and council enacted the Water Framework Directive (WFD) which has set an ecosystem-based regulation. It holds undisturbed conditions of freshwaters as references defined in different hydro-ecoregions and requires economic justification for any development resulting in a significant gap between the current status of a water body and its reference. Designed as a 
To be cited as : Bouleau, G., C. Argillier, Y. Souchon, C. Barthélémy and M. Babut (2009). "How ecological indicators construction reveals social changes - the case of lakes and rivers in France." Ecological Indicators 9 (6): 1198-1205.

masterpiece of binding legislation for European waters, the WFD created favourable conditions to break down the previous locked-in fits of the French freshwater monitoring.

Freshwater biologists re-processed the thirty-year database of faunistic inventories used for IBGN to identify eco-regional references for rivers (Khalanski and Souchon 1994; Wasson, Chandesris et al. 2003). Others compiled records on fish population to calibrate a "fish index" (Oberdorff, Pont et al. 2002). Further research is currently underway to better understand how already monitored biological assemblages respond to contamination (Archaimbault, Garric et al. 2005). More research is required to calibrate indicators for compartments that were previously little monitored such as diatoms and macrophytes. French lake specialists were spurred to update the 'rapid diagnosis' method according to WFD standards, i.e. better considering environmental and morphological heterogeneity, including missing biological information (abundance of taxa for example). Previous ecological research on Alpine lakes was reprocessed accordingly to propose new index WFD compliant (phytoplankton and macrobenthos index) Nevertheless, this integrative approach was mainly calibrated for the quality assessment of natural lakes of the Alpine area and remained less reliable on other lakes. Moreover, because fish experts and botanists hardly explored lakes in France before the WFD was enacted, fish and macrophytes are still to be studied in a bioindication perspective. Relationships between fish assemblages and environmental factors have been studied (Argillier, Pronier et al. 2002; Argillier, Pronier et al. 2002; Irz, Odion et al. 2005), but EI development are still under development at the national level.

These two cases ('rapid diagnosis' and fish index) show how EI initially designed for a specific political arena can be reshaped to fit another one. Regional EI promoters may get institutional support above state level (European Community) to impose the legal framework favourable to the implementation of EI at lower level. This requires that EI promoters, who initially worked at regional scale, shall reprocess their indicators to meet international specifications. When no previous research was conducted at national level, data must be collected in the first place. To reduce this endeavour, experts promote their methods at European level. Yet few adaptations to regional features remain enshrined in EI and impair their universality.

\section{Conclusion: a cumulative and adaptive model of social trajectories of EI}

This study is meant to be inductive and allows us to derive a theoretical framework from observations. Bioindication tools we studied were never optimised for the present market or political arena but rather recycled. Their development was (a) adaptive, i.e. innovative to respond to new questions; (b) constrained by law; and (c) cumulative, i.e. built on what already existed.

(a) We observed innovative ecological monitoring stemming from regional outsiders who wanted to address a new water quality problem raised by a social minority. Interaction between regional scientists and the social minority framed the issue (double arrow in Fig.iii). Actors reluctant to admit the problem asked for evidence (Fig. iii shows no direct influence from innovation to implementation). The burden of the proof rested on EI developers, who adapted previously existing data and knowledge to their specific concern. It consisted of changing the format of data and including new information, very often without immediate recognition. From adapted and new gathered data, they induced ecological causal relationships. They refined protocols in order to address more specifically the problem. At this stage, ecological data were not framed as indicators - i.e. decision support tools - they were only variables. But variables could be mapped in space and monitored in time. This phase is called "adaptation" in Fig. iii.

(b) New EI promoters experienced difficulty in convincing existing institutions and did not get much funding for implementing their monitoring. Some failed to convince other actors and went on adapting their tools at regional level. Others were able to raise larger public attention or to meet other stakeholders' concerns who joined in "advocacy coalitions" (Sabatier and Jenkins-Smith 1999). Negotiations required quantification and standardization. Variables that were previously only used by activists became "passage points" (Star and Griesemer 1989) for many different actors and got standardized. People translated their interests using such variables, and spread their use. Successful EI promoters found a suitable political 
To be cited as : Bouleau, G., C. Argillier, Y. Souchon, C. Barthélémy and M. Babut (2009). "How ecological indicators construction reveals social changes - the case of lakes and rivers in France." Ecological Indicators 9 (6): 1198-1205.

arena for changing law despite institutional resistance to change and got their EI institutionalized. We illustrate this phase with the box "institutions" in Fig. iii.

(c) Evolutions we studied were also cumulative processes. Once enacted, a new law imposed that a successful EI had to be regularly monitored. It transferred the burden of the proof onto projects initiators whose plans might harm freshwaters or made the state responsible for collecting data. It spread the use of new EI outside the region where it was developed. Given the cost of developing an EI, recycling prevailed. Systematic monitoring got established and data became available for further research. We call this phase "accumulation" in Fig. iii. Yet regional fits of the EI were often kept in this process. Moreover the inertia of the routine worked as a locked-in fit preventing other EI to be adopted. Adaptive management is limited (dotted line in Fig. iii). Therefore new environmental problems could hardly be seen through mainstream monitoring and required another cycle of adaptation (a).

This analytical model applies in the development of all the five EI we studied, (i.e. saprobic index, test on minnows, biotic index, 'rapid diagnosis', and fish index). It reveals the evolution of French water management in two ways. The emergence of an EI corresponds to the emergence of an ecological problem mainly ignored by authorities. Secondly groups of biota used for the construction of an EI reveal a converging interest of different stakeholders for the same type of information at one historical moment. We inherit from EI that fit the social context of their emergence. New phases of adaptation may be required to adjust them to our current concerns. It enlightens weaknesses of the models illustrated in Fig. i and Fig. ii and supports the theoretical framework presented in Fig. iii. The adaptation phase accounts for innovations mainly due to outsiders who seek opportunities for institutionalization. Implementation is more an accumulation phase secured by regular funding than one of selection or adaptation.

This analytical framework helps us addressing the initial question: "why EI seem to be hardly used to support decisions, management plans, and programs evaluations?" In the adaptation phase, outsiders raise the alarm without bending the trend of the current management. They collect new data and reprocess available information in order to convince others. This phase can be long and very frustrating. Biologists get little support and often complain about indifferent decision-makers. Institutional recognition on the contrary is a sudden shift which challenges the existing water management. Authorities seek new solutions. EI are used to assess pilot restoration techniques. Soon best practices emerge and got standardized. Managers make plans and programs based on such standards. They used EI to define targets but EI do not influence everyday decisions. Bad records may raise the attention of the public and the decision makers. But if the problem is settled enough, social mobilization declines. In such cases EI are monitored by precaution rather than decision support. Hence two kinds of EI exist, the ones addressing an issue that is not yet acknowledged and the ones monitoring a problem already tackled. The period inbetween is too short to get noticed. One should not base the righteousness of EI according to their influence on everyday decisions. On the contrary, the virtue of environmental indicators is to put into question paradigms of management. And this may not happen everyday. On a regular basis EI are collected for the sake of accumulation of data and knowledge. They will constitute a valuable resource for the next outsiders tracking regional biases of existing EI and revealing unnoticed environmental problems.

\section{Acknowledgements}

This work was financially supported by Cemagref call for research "MAITRISES". The authors are grateful to the scientists, managers and stakeholders interviewed for the purpose of this study. The paper benefited from valuable discussions with and wise advice of Tim Duane, Adina Merenlender, Stefania Barca, and Matt Kondolf from University of California at Berkeley. The authors would like to thank Delaine Sampaio, Christelle Gramaglia and Julie Trottier and two anonymous reviewers for their helpful comments and suggestions. 
To be cited as : Bouleau, G., C. Argillier, Y. Souchon, C. Barthélémy and M. Babut (2009). "How ecological indicators construction reveals social changes - the case of lakes and rivers in France." Ecological Indicators 9 (6): 1198-1205.

\section{Figures}

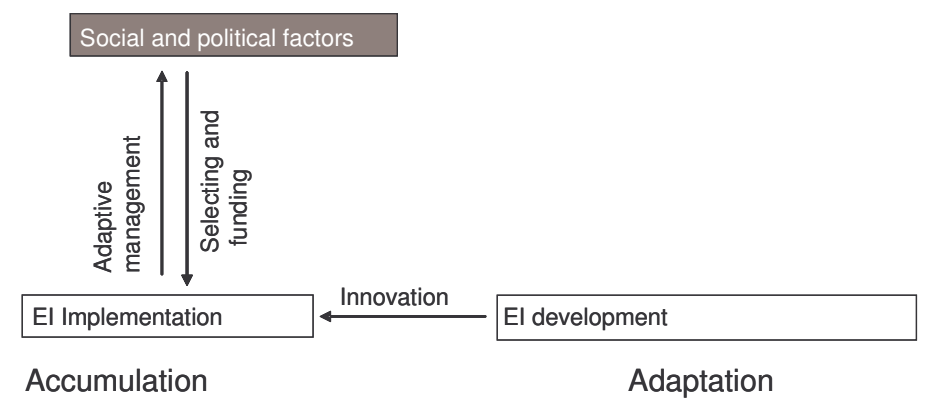

Fig. 1. To date, authors have studied a small loop of feedback between social and political factors and EI implementation. They have not addressed the social and political influences on the EI development.

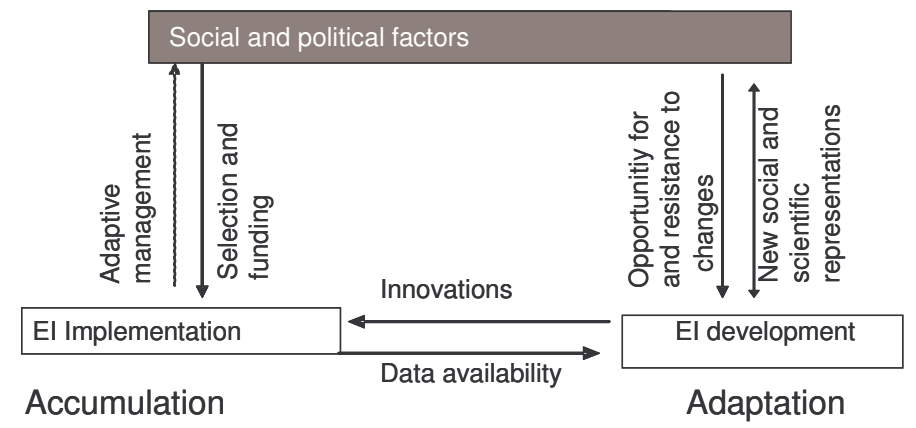

Fig. 2. We propose to address a larger loop of social interactions in which EI development is also included. This approach enables to take into account influences of data availability, changes in social and scientific representations, opportunity and resistance to changes.

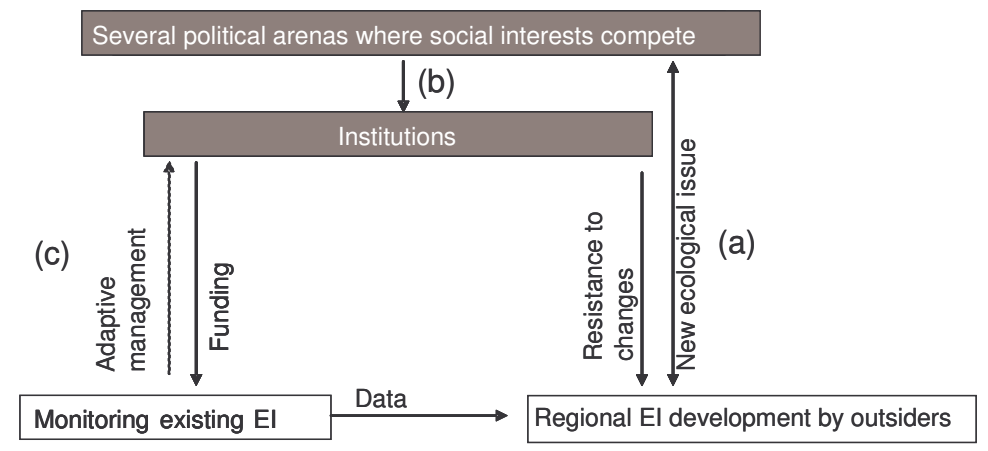

Accumulation

Adaptation 
To be cited as : Bouleau, G., C. Argillier, Y. Souchon, C. Barthélémy and M. Babut (2009). "How ecological indicators construction reveals social changes - the case of lakes and rivers in France." Ecological Indicators 9 (6): 1198-1205.

Fig. 3. Our analytic framework presents a regional level where EI are initially developed by outsiders raising new ecological issues and adapting data inherited from a former phase (a). It distinguishes several political arenas where social interests compete and may offer opportunities to institutionalize EI at one level (b). Such institutionalization secures systematic funding for monitoring and data accumulation but limit adaptive management (c).

\section{References}

Altheide, D. L. (1996). Ethnographic Content Analysis. In Qualitative Media Analysis. D. L. Altheide, Ed. Thousands Oaks London New Delhi, Sage Publications Inc: 13-22.

Amoros, C., A. L. Roux, J. L. Reygrobellet, J. P. Bravard and G. Pautou (1987). "A method for applied ecological studies of fluvial hydrosystems " Regulated Rivers 1 (1): 17-36.

Archaimbault, V., J. Garric, M. Babut, P. Usseglio-Polatera and J. Wasson (2005). "Biological And Ecological Responses Of Macrobenthic Assemblages To Sediment Contamination In French Streams." Eos Trans. AGU, 86 (18) Jt. Assem. Suppl.

Argillier, C., O. Pronier and P. Irz (2002). "Approche typologique des peuplements piscicoles lacustres Français. I. Les communautés des plans d'eau d'altitude supérieure à 1500 m." Bulletin Français de Pêche et de Pisciculture (365/366): 373-387.

Argillier, C., O. Pronier, P. Irz and O. Molinier (2002). "Approche typologique des peuplements piscicoles lacustres Français. II. Structuration des communautés dans les plans d'eau d'altitude inférieure à 1500m." Bulletin Français de Pêche et de Pisciculture (365/366): 389-404.

Aspe, C. (1995). "Construction sociale des normes et mode de pensée environnemental." Sciences, Sociétés, Environnement, Actes de l'Ecole d'été Européenne: 231-243.

Aubin, D. and F. Varone (2002). European Water Policy. A path towards an integrated resource management. Louvain-la-neuve, EUWARENESS: 28.

Barbe, J., E. Lavergne, G. Rofes, M. Lascombe, J. Rivas, C. Bornard and J. DeBenedittis (1990). "Diagnose rapide des plans d'eau." Informations Techniques du Cemagref 79 (2): 8.

Barbour, M. T., W. F. Swietlik, S. K. Jackson, D. L. Courtemanch, S. P. Davies and C. O. Yode (2000). "Measuring the attainment of biological integrity in the USA: A critical element of ecological integrity." Hydrobiologia 422-423: 453-464.

Barles, S. and L. Lestel (2007). "The Nitrogen Question: Urbanization, Industrialization, and River Quality in Paris, 1830-1939." Journal of Urban History (33): 794- 812.

Barroin, G. (2004). "Phosphore, azote, carbone... du facteur limitant au facteur de maittrise." Le courrier de l'environnement de l'INRA 52: 1-25.

Barthélémy, C. (2003). Des rapports sociaux à la frontière des savoirs. Les pratiques populaires de pêche amateur au défi de la gestion environnementale du Rhône. doctorat UFR Sciences Humaines, Aix-Marseille I: 378.

Beisel, J.-N., P. Usseglio-Polatera, S. Thomas and J.-C. Moreteau (1998). "Stream community structure in relation to spatial variation: the influence of mesohabitat characteristics " Hydrobiologia 389 $(1 / 3): 73-88$.

Bouleau, G. (2007). La gestion française des rivières et ses indicateurs à l'épreuve de la directive cadre. Thèse de doctorat Sciences de l'environnement. Paris, AgroParisTech - ENGREF: 457.

Bovee, K. and R. Milhous (1982). A Guide to Stream Habitat Analysis Using Instream Flow Incremental Methodology. Instream Flow Information Paper $\mathrm{n}^{\circ} 12$ FWS/OBS 82/26, Western Energy and Land Use Team. Fish and Wildlife services. Fort Collins, Colorado: 248.

Bryman, A. and R. G. Burgess (1994). Qualitative Research Methodology - A review. In Analysing Qualitative Data. A. Bryman and R. G. Burgess, Eds. London New York, Routledge: IX XXXIV. 
To be cited as: Bouleau, G., C. Argillier, Y. Souchon, C. Barthélémy and M. Babut (2009). "How ecological indicators construction reveals social changes - the case of lakes and rivers in France." Ecological Indicators 9 (6): 1198-1205.

Cairns, J. J. and J. R. Pratt (1993). A history of biological monitoring using benthic macroinvertebrates. In Freshwater biomonitoring and benthic invertebrates. D. M. Rosenberg and V. H. Resh, Eds. New York, Chapman \& Hall: 10-27.

Callon, M. (1986). Some elements of a sociology of translation: domestication of the scallops and the fishermen of Saint Brieuc Bay. In Power, Action and Belief: A New Sociology of Knowledge? Sociological Review Monograph. J. Law, Ed. London, Routledge and Kegan Paul. 32: 196-233.

Canfield, D. E. (1983). "Prediction of chlorophyll a concentrations in Florida lakes: the importance of phosphorus and nitrogen." Water Resources Bulletin (19): 255-262.

Carlson, R. E. (1977). "A trophic state index for lakes." Limnology and Oceanography (22): 361-369.

Castella, E., M. Richardot-Coulet, C. Roux and P. Richoux (1984). "Macroinvertebrates as 'describers' of morphological and hydrological types of aquatic ecosystems abandoned by the Rhône River." Hydrobiologia 119 (3): 219-225.

Colson, A. and P.-Y. Cusset (2005). "Revisiting a futures studies project--'Reflections on 1985'." Futures 37 (10): 1057-1065.

Corbin, A., Ed. (1995). L'avénement des loisirs (1850-1960). Paris, Champs Flammarion: 467.

Dale, V. H. and S. C. Beyeler (2001). "Challenges in the development and use of ecological indicators." Ecological indicators 1 (1): 3-10.

Davis, M. A. and L. B. Slobodkin (2004). "The Science and Values of Restoration Ecology." Restoration Ecology 12 (1): 1-3.

Dillon, P. J. and F. H. Rigler (1974). "The phosphorus-chlorophyll relathionship in lakes." Limnology and Oceanography (19): 767-773.

Fabiani, J.-L. (1985). Sciences des écosystèmes et protection de la nature. In Protection de la nature. Histoire et idéologie. De la nature à l'environnement. A. Cadoret, Ed. Paris, Edition L'Harmattan: 75-93.

Fleck, L. (1979). Genesis and Development of a Scientific Fact, University of Chicago Press: 203.

Forsyth, T. (2003). Critical Political Ecology: The Politics of Environmental Science. London, Routledge: 320.

Foucault, M. (1978-79). Naissance de la biopolitique. Cours au Collège de France 1978-1979. Paris, Gallimard Seuil.

Goubert, J.-P. (1986). La conquête de l'eau. L'avènement de la santé à l'âge industriel. Paris, Hachette Pluriel: 302 .

Higgs, E. (1994). "Expanding the scope of restoration ecology." Restoration Ecology 2: 137-146.

Hobbs, R. J. (2004). "Restoration ecology: the challenge of social values and expectations." Frontiers in Ecology and the Environment 2 (1): 43-48.

Irz, P., M. Odion, C. Argillier and D. Pont (2005). Comparison between the fish communities of lakes, reservoirs and rivers: can natural systems help define the ecological potential of reservoirs? International Symposium on assessing the ecological status of rivers, lakes and transitional waters, Hull, UK, 11-15 June 2005.

Jackson, L., N. Lopoukhine and D. Hillyard. (1995). "Ecological restoration: a definition and comments." Restoration Ecology 3: 71-75.

Kallis, G. (2007). "Socio-environmental co-evolution: some ideas for an analytical approach." International Journal of Sustainable Development and World Ecology 14 (1): 4-13.

Kallis, G. and P. Nijkamp (2000). "Evolution of EU water policy: A critical assessment and a hopeful perspective." Zeitschrift für Umweltpolitik und Umweltrecht (ZfU) (3): 301-335.

Karr, J. R. (1981). "Assessment of Biotic Integrity using fish communities." American Fisheries Society 6 (6): 21-27.

Karr, J. R. (1991). "Biological Integrity: A Long-Neglected Aspect of Water Resource Management " Ecological applications 1 (1): 66-84.

Karr, J. R. (1993). "Defining and assessing ecological integrity beyond water quality." Envir. Tox. Chem. (12): 1521-1531. 
To be cited as: Bouleau, G., C. Argillier, Y. Souchon, C. Barthélémy and M. Babut (2009). "How ecological indicators construction reveals social changes - the case of lakes and rivers in France." Ecological Indicators 9 (6): 1198-1205.

Khalanski, M. and Y. Souchon (1994). Quelles variables biologiques pour quels objectifs de gestion ? In Etat de santé des écosystèmes aquatiques - les variables biologiques comme indicateurs. $\mathrm{N}$. Chartier-Touzé, Y. Galvin, C. Levêque and Y. Souchon, Eds. Paris, 2 \& 3 novembre: 67-109.

Kneese, A. V. (1962). Water Pollution: Economic Aspects and Research Needs. Baltimore, Johns Hopkins Press: 107.

Kolkwitz, R. and M. Marsson (1908). "Okologie des pflanzlichen saprobien." Berichte der Deutschen botanischen Gesellschaft 26: 505-519.

Kondolf, G. M., S. Anderson, R. Lave, L. Pagano, A. Merenlender and E. S. Bernhardt (2007). "Two Decades of River Restoration in California: What Can We Learn?" Restoration Ecology 15 (3): $516-523$

Lackey, R. T. (2001). "Values, policy, and ecosystem health." Bioscience 51: 437-443.

Lafont, M. (1989). Contribution à la gestion des eaux continentales : utilisation des oligochètes comme descripteurs de l'état biologique et du degré de pollution des eaux et des sédiments. Lyon I, Université Claude Bernard. Thèse d'Etat.

Lafont, M., J. Juget and G. Rofes (1991). "Un indice biologique lacustre basé sur l'examen des oligochètes." Revue des Sciences de 1'Eau (4): 253-268.

Lang, C. (1985). "Eutrophication of Lake Geneva indicated by the oligochaete communities of the profundal " Hydrobiologia 126 (3): 237-243.

Latour, B. (1987). Science in action. Cambridge, Harvard University Press.

Lenat, D. R. and M. T. Barbour (1994). Using Benthic Macroinvertebrates Community Structure for Rapid, Cost-effective, Water Quality Monitoring: Rapid Bioassessment. In Biological Monitoring of Aquatic Systems. S. L. Loeb and A. Spacie, Eds., Lewis Publishers: 187-215.

Lenz, R. and D. Peters (2006). "From data to decisions: Steps to an application-oriented landscape research." Ecological Indicators 6 (1): 250-263

McNie, E. C. (2007). "Reconciling the supply of scientific information with user demands: an analysis of the problem and review of the literature " Environmental Science \& Policy 10 (1): 17-38.

Milhous, R. T. (1979). The PHABSIM system for instream flow studies. Summer Computer Simulation Conference, Toronto, Ontario, Society for computer simulation, La Jolla, CA.,

Moog, O. and A. Chovanec (2000). "Assessing the ecological integrity of rivers: walking the line among ecological, political and administrative interests." Hydrobiologia 422-423 (0): 99-109.

Mouchel, J.-M. (1986). Essai de définition d'un protocole de diagnose rapide de la qualité des eaux des lacs. Utilisation d'indices trophiques. Noisy le Grand, C.E.R.G.R.E.N.E. - Ecole Nationale des Ponts et Chaussées: 57.

Mouchel, J.-M. (1987). Essai de définition d'un protocole de diagnose rapide de la qualité des eaux des lacs. Utilisation des indices trophiques. Noisy le Grand, C.E.R.G.R.E.N.E.: 24.

Mouthon, J. (1993). "Un indice biologique lacustre basé sur l'examen des peuplements de mollusques." Bulletin Français de Pêche et de Pisciculture (331): 397-406.

Nicolazo, J.-L. (1993). Les agences de l'eau. Paris, Pierre Johanet et Fils Editeurs: 207.

Oberdorff, T., D. Pont, B. Hugueny and J.-P. Porcher (2002). "Development and validation of a fishbased index for the assessment of 'river health' in France." Freshwater Biology (47): 1720-1734.

Pigou, A. C. (1920). The Economics of Welfare. Londres, Mac Millan.

Pont, D., B. Hugueny, U. Beier, D. Goffaux, R. Noble, C. Rogers, N. Roset and S. Schmutz (2006). "Assessing the biotic integrity of rivers at the continental scale: a European approach." Journal of Applied Ecology (43): 70-80.

Rabinow, P. (1989). French Modern: Norms and Forms of the Social Environment, MIT Press: 447.

Ribaudo, M. O., D. L. Hoag, M. E. Smith and R. Heimlich (2001). "Environmental indices and the politics of the Conservation Reserve Program." Ecological indicators 1: 11-20.

Richardot-Coulet, M., E. Castella and C. Castella (1987). "Classification and succession of former channels of the French upper rhone alluvial plain using mollusca " Regulated Rivers: Research and Management 1 (2): 111 - 127. 
To be cited as : Bouleau, G., C. Argillier, Y. Souchon, C. Barthélémy and M. Babut (2009). "How ecological indicators construction reveals social changes - the case of lakes and rivers in France." Ecological Indicators 9 (6): 1198-1205.

Roux, A.-L., Ed. (1982). Cartographie polythématique appliquée à la gestion écologique des eaux. Etude d'un hydrosytème fluvial : le Haut-Rhône français. Paris, PIREN CNRS.

Sabatier, P. A. and H. C. Jenkins-Smith, Eds. (1993). Policy change and learning, an advocacy coalition approach. Boulder, Westview Press: 290.

Sabatier, P. A. and H. C. Jenkins-Smith (1999). The Advocacy Coalition Framework. An Assessment. In Theories of the policy process. P. A. Sabatier, Ed. Boulder, Westview Press.

Shields, D. J., S. V. Solar and W. E. Martin (2002). "The role of values and objectives in communicating indicators of sustainability." Ecological Indicators 2 (1-2): 149-160

Souchon, Y., S. Valentin and H. Capra (1998). "Peut-on rendre plus objective la détermination des débits réservés par une approche scientifique ? " La Houille Blanche (8): 41-45.

Star, S. L. and J. R. Griesemer (1989). "Institutional Ecology, 'translations' and Boundary Objects: Amateurs and Professionals in Berkeley's Museum of Vertebrate Zoology, 1907-39." Social Studies of Science 19 (387): 387-420.

Statzner, B., V. Resh and S. Dolédec (1994). Ecology of the Upper Rhône River: a test of habitat templet theories, Blackwell Scientific.

Statzner, B., V. Resh and A. Roux (1994). "The Synthesis of Long-term Ecological Research in the Context of Concurrently Developed Ecological Theory: Design of a Research Strategy for the Upper Rhone River and Its Floodplain " Freshwater biology 31 (3): 253-263.

Tennant, D. L. (1976). Instream flow regimes for fish, wildlife, recreation and related environmental resources. In Instream Flow Needs. J. F. Orsborn and C. H. Allman, Eds. Bethesda, Maryland, American Fisheries Society, Western Division. 2: 359-373.

Trottier, J. (2008). "Water crises: political construction or physical reality." Contemporary Politics 14 (2): 197-214.

Trottier, J. and P. Slack (2004). Managing Water Resources Past and Present, Oxford University Press: 185.

Tufféry, G. and J. Verneaux (1967). Méthode de détermination de la qualité biologique des eaux courantes - exploitation codifiée des inventaires de la faune de fond., Trav. Div. Qual. Eaux P. Pisc C.T.G.R.E.F.: 23.

Turnhout, E., M. Hisschemöller and H. Eijsackers (2006). "Ecological indicators: Between the two fires of science and policy." Ecological indicators 7 (2): 215-228.

Usseglio Polatera, P., M. Bournaud, P. Richoux and H. Tachet (2000). "Biological and ecological traits of benthic freshwater macroinvertebrates: relationships and definition of groups with similar traits." Freshwater Biology 43 (2): 175-205.

Verneaux, J. (1973). Cours d'eau de Franche-Comté (Massif du Jura). Essai de biotypologie. Mémoire de thèse d'Etat Sciences Naturelles. Besançon, Université de Besançon: 200.

Verneaux, J. and G. Tuffery (1967). "Une méthode zoologique pratique de détermination de la qualité biologique des eaux courantes. Indices biotiques." Annales Scientifiques de l'Université de Besançon (Zoologie) 3: 79-90.

Vollenweider, R. A. and J. J. Kerekes (1980). Synthesis report. OECD cooperative programme on monitoring of inland waters (eutrophication control): 290.

Wasson, J.-G., A. Chandesris, H. Pella and L. Blanc (2003). Typologie des eaux courantes pour la directive cadre européenne sur l'eau : l'approche par hydro-écorégion. Mise en place de systèmes d'information à références spatiales (SIRS). Actes du Vè séminaire, Montpellier, Cemagref Editions, 13-14 novembre 2003.

Woodiwiss, F. S. (1964). "The biological system of stream classification used by the Trent River Board." Chemistry and Industry: 443-447. 